\title{
RADIAL ARTERY ANOMALIES IN THE MACEDONIAN POPULATION DURING TRANSRADIAL ANGIOGRAPHY PROCEDURES
}

\author{
Zafirovska Biljana, Petkoska Danica, Antov Slobodan, Vasilev Ivan, \\ Jovkovski Aleksandar, Kalpak Oliver, Kostov Jorgo, Spiroski Igor, Pejkov Hristo, \\ Bosev Marjan, Taravari Hajber, Kitanoski Darko, Kedev Sasko \\ University Clinic of Cardiology, University of Sts.Cyril and Methodius, Skopje, R. Macedonia
}

Primljen/Received 13. 05. 2016. god.

Abstract: Objective: To assess the incidence of arterial anomalies of the radial artery in the Macedonian population registered during transradial access (TRA) angiography procedures in a large series of patients.

Background: Transradial angiography (TRA) is now the recommended access for percutaneous coronary intervention, but technically is a more challenging approach for angiography procedures mostly due to the anatomic anomalies on the radial artery, which may influence the success rate of transradial angiographic procedures.

Methods: All consecutive 19292 patients from our Center, in the period from March 2011 until December 2014 were examined. Preprocedural radial artery angiography was performed in all patients. Clinical and procedure characteristics, type and incidence of vascular anatomy variants and access site complications were analyzed.

Results: Anatomical variants were present in 1625 (8.8\%) patients. The most frequent was high-bifurcating radial artery origin from the axillary and brachial arteries in 1017 (5.5\%) patients, 227 (1.2\%) had extreme radial artery tortuosity, $176(0.95 \%)$ had a full radial loop, $32(0.17 \%)$ with hypoplastic radial artery and 173 $(0.9 \%)$ had tortuous brachial, subclavian and axillary arteries. Radial artery spasm was very common in patients with present radial artery anomalies.

Conclusion: Radial artery anomalies are very common in the general population. Knowing the anatomy of the radial artery helps the interventional cardiologist in successfully planning and performing this procedure. Radial artery angiography is strongly encouraged in every patient before the begining of the transradial angiography procedures.

Keywords: TRA (Transradial artery access), RA (Radial artery), TFA (Transfemoral artery access), Vascular anatomy variants.
Prihvaćen/Accepted 12. 06. 2016. god.

\section{INTRODUCTION}

Trans radial access (TRA) is now the preferred access site for percutaneous cardiovascular interventions in experienced radial centers (1).

Radial artery anomalies are frequently found in the general population. Autopsy studies of upper limbs have found arterial anatomical variations in between $4 \%$ and $18.5 \%,(2,3)$ while arteriography studies reported percentages between $7.4 \%$ and $22.8 \%(4-7,8,9)$.

Multiple studies support transfer from femoral artery access to radial access for all angiographic diagnostic and interventional procedures mostly due to decreasing access site bleeding and vascular complications without sacrificing procedural success $(10,11,12,13)$. The radial approach improves patient comfort and satisfaction, allows rapid ambulation and is associated with reduced cost and hospital stay $(10,11,12,13)$.

Patients with increased risk of bleeding and vascular complications have a particular benefit from TRA as opposed to transfemoral approach (TFA): female gender, elderly, obesity, low weight, hypertension, renal failure, low platelet count and anemia (10, $11,12,13)$.

Transradial approach as opposed to transfemoral approach is a technically more challenging approach mostly due to the present radial artery anatomic anomalies, which may influence the success rate and procedure time of transradial angiographic procedures $(4,5$, $6,7)$. Prior studies have reported that radial arterial anomalies can influence the success of transradial access and are cause for access crossover from TRA to other access sites $(4,5,6,7)$.

It is important that interventionalists learning the transradial technique while performing angiography procedures become familiar with common anatomic 
radial artery anomalies and learn how to navigate through them.

Most experienced transradial operators in high volume transradial centers can overcome these anomalies and successfully perform their procedures without prolonging procedure time.

In this study we evaluate the incidence of these variations in the Macedonian population during transradial approach angiography procedures in a large cohort of patients from a national PCI (percutaneous coronary interventions) referral center.

\section{MATERIALS AND METHODS}

\section{Patient population}

This was a prospective single center study including all patients from March 2011 to December 2014 referred for coronary or peripheral angiography to a large volume tertiary referral center at the University Clinic of Cardiology, Skopje, Macedonia.

Table 1. Arterial access

\begin{tabular}{|l|c|}
\hline \multicolumn{1}{|c|}{ Clinical Variables } & $\begin{array}{c}\text { Total N of Patients } \\
\mathbf{N}=\mathbf{1 9 2 9 2}\end{array}$ \\
\hline TRA & $18417(95.4 \%)$ \\
\hline TUA & $812(4.2 \%)$ \\
\hline TFA & $53(0.3 \%)$ \\
\hline TBA & $10(0.05 \%)$ \\
\hline
\end{tabular}

* TRA — Transradial access; TUA — transulnar access; TFA — transfemoral access; TBA — transbrachial access

All procedures were performed by experienced transradial operators ( $>500$ diagnostic TRA procedures and $>300$ PCI procedures per year). Radial artery angiography was performed in all patients to evaluate the presence of any anatomic variation of the arteries. Total number of procedures done in that period was 19292. Transradial access was performed in $95 \%$ (18417), transulnar access with $4,2 \%(812)$, transfemoral $0,3 \%$ (53) and transbrachial access in $0,05 \%$ of all procedures (Table 1 ).

\section{Radial artery puncture and cannulation}

After local anesthesia with $1 \mathrm{ml}$ lidocaine $2 \%$, radial artery (RA) puncture was performed with a sheath set, including a 20 gauge 2-piece needle, 0.025 inch straight wire and a $16-\mathrm{cm} 6 \mathrm{Fr}$ or $5 \mathrm{~F}$ sheath. Following sheath insertion, a drug cocktail consisting of verapamil $(5 \mathrm{mg})$ and heparin $(3000 \mathrm{U})$ was administered through the sheath sidearm.

In case of interventional procedures weight adjusted Heparin $(100 \mathrm{U} / \mathrm{kg})$ was administered through the sheath before the start of the procedure.
Retrograde radial arteriography was performed after administration of the arterial vasodilatator to define the radial artery anatomy from mid forearm to ulnobrachial anastomosis and to delineate ulnar artery anatomy as well, generating a roadmap for the intervention. A solution of $3 \mathrm{ml}$ of contrast (Ultravist 370) diluted with $7 \mathrm{ml}$ of blood was injected through the cannula or through the side arm of the sheath under fluoroscopy in AP position. If anomalous anatomy was identified, the operator planned the procedure on that basis. Retrograde arteriography is of particular importance when there is some resistance in guidewire advancement and in patients after previous transradial interventions. If the operator identified a possible anomaly in brachial, axillar or subclavian arteries, an arteriogram higher up the arm was obtained.

In case of radial access failure, transfer was done to ipsilateral ulnar artery or to the left radial artery or transfemoral artery depending on operator preference. Only 3 cases with anomalies required transfer to femoral access.

Post procedure management: The sheath was removed immediately after the procedure, regardless of the level of anticoagulation, and a compressive dressing or closure device was applied to the wrist. In our practice we use TR band or simple compressive dressing. In order to decrease the rate of radial artery occlusion we applied patent hemostasis by using pulse oximetry to confirm the hemoglobin oxygen saturation on the punctured radial artery $(>90 \%)$, after hemostasis was obtained (during measurement UA was compressed manually). Compression was applied for approximately a 2 to 3 -hour period with gradual relaxation of compression or deflation of the TR band after the 1st hour.

\section{Aim of study}

The aim of this study was to access the incidence of radial artery anomalies in the Macedonian population. Procedural time and fluoroscopy time was analysed. Complications during the procedure as radial artery spasm and haemathoma were recorded after every procedure.

\section{Definitions}

A high bifurcating origin of the radial artery was defined as the origin of the radial artery from the brachial or axillary artery proximal to the upper border of the cubital fossa.

Radial artery loop was defined as presence of a full 360 degrees loop of the radial artery, with or without the presence of a remnant radial artery (Figure 1). 


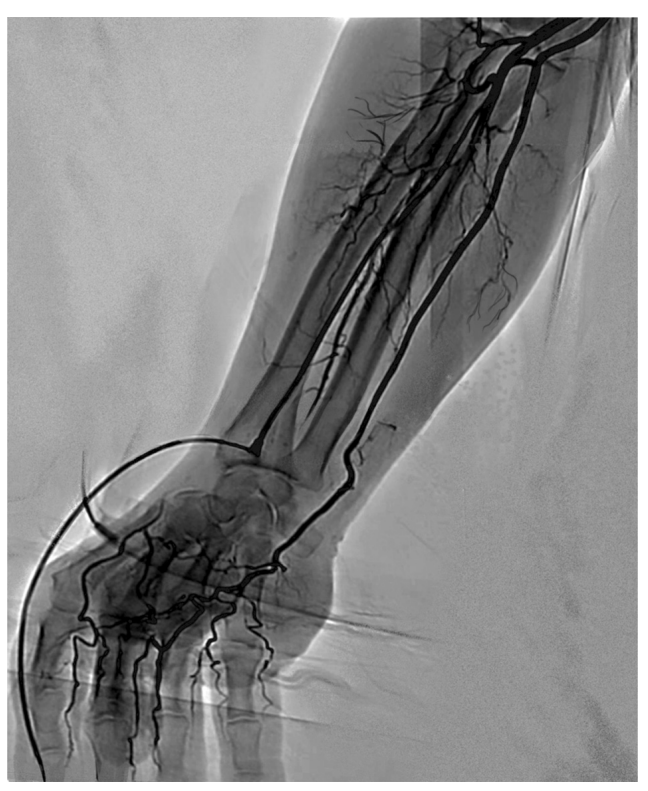

Figure 1. Radial artery loop

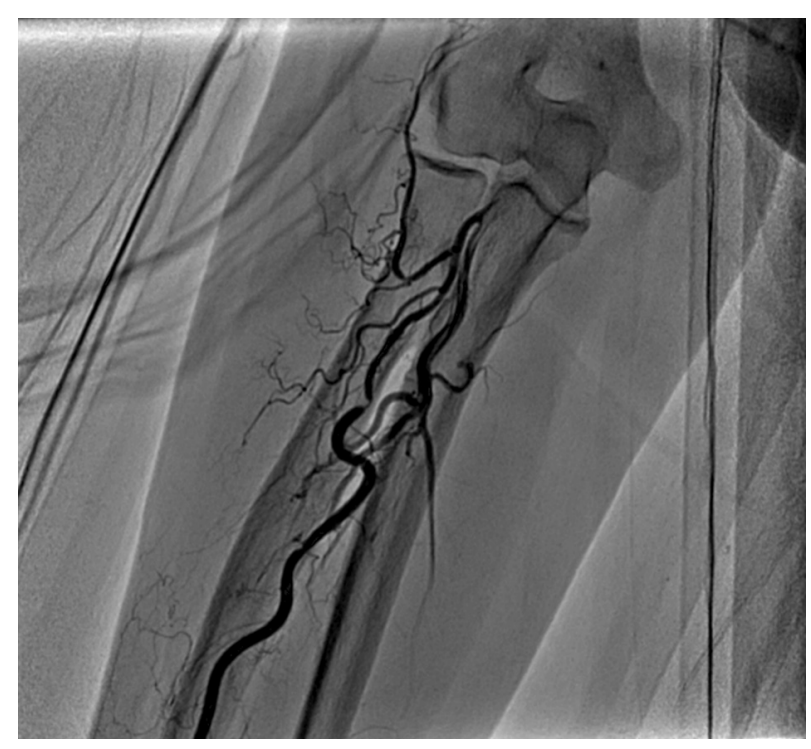

Figure 2. Radial artery tortuosity

Radial, brachial and subclavian artery tortuosity was defined as presence of a curve of more than 45 degrees in the vessel (Figure 2).

Clinical radial artery spasm (RAS) was classified as grade I: minimal local pain and disconfort; grade II: significant local pain and discomfort, not precluding procedure completition; grade III: severe local pain and disconfort necessiting cross over and grade IV: catheter entraptment with severe local pain and disconfort $(14,15)$.

Vascular access site complications were defined as the occurence of an aneurysm, fistula, hematoma, loss of radial pulse or radial nerve injury.

Hematoma was classified into five grades (grade I: local hematoma, superficial $<5 \mathrm{~cm}$; grade II: hematoma with moderate muscular infiltration; grade III: forearm hematoma and muscular infiltration, below the elbow; grade IV: hematoma and muscular infiltration extending above the elbow; grade $\mathrm{V}$ : ischemic threat compartment syndrome) (16).

\section{Statistical analysis}

Simple descriptive statistics was used. For normally distributed numeric variables, data was expressed as mean \pm standard deviation and for continuous variables not fitting a normal distribution as median (minimum-maximum). Percentages were used to express categorical variables. Chi-square test was used to compare categorical variables and student's t-test was used to compare differences between two groups. A P-value of $<0.05$ was considered statistically significant. Statistical analysis were performed with SPSS 17.0 for Windows (SPSS Inc. Chicago, ILL).

\section{RESULTS}

From 19292 consecutive transradial procedures, anatomical variants were present in 1625 (8.8\%) patients. From baseline caracteristics $66 \%$ of patients with present anomalies were male, with medium BMI of 23 (19-43). Diabetes was present with $19 \%$ and hypertension with $67 \%$. $22 \%$ of patients with STEMI (acute myocardial infarction procedures with ST segment elevation) had RA anomalies. There was no significant difference in procedure or fluoroscopy time of patients with anomalies compared to the general population.

Patients with RA anomalies in the Macedonian population had median age of 62 (27-90) higher than the median age of the general population without RA anomalies which was 52 years (18-91) (Table 2).

Table 2. Baseline characteristics of patients with TRA

\begin{tabular}{|c|c|c|}
\hline Clinical Variables & $\begin{array}{c}\text { Total N Patients } \\
(\mathrm{N}=18417)(95,4 \%)\end{array}$ & $\begin{array}{c}\text { Patients with } \\
\text { RA anomalies } \\
(\mathrm{N}=1625)(8,8 \%)\end{array}$ \\
\hline Age (years) & $52(18-91)$ & $62(27-90)$ \\
\hline Male & $12750(70 \%)$ & $1076(66 \%)$ \\
\hline Female & $5667(30 \%)$ & $503(31 \%)$ \\
\hline BMI $\left(\mathrm{kg} / \mathrm{m}^{2}\right)$ & $25(19-47)$ & $23(19-43)$ \\
\hline \multicolumn{3}{|l|}{ CAD risk factors } \\
\hline Hypertension & $13704(74 \%)$ & $1086(66,8 \%)$ \\
\hline Diabetes mellitus & $4422(24 \%)$ & $312(19,2 \%)$ \\
\hline Dyslipidemia & $5010(27 \%)$ & $372(22,9 \%)$ \\
\hline Smoking & $5535(30 \%)$ & $453(27,8 \%)$ \\
\hline PCI & $8965(48,6 \%)$ & $768(47,2 \%)$ \\
\hline CAS & $2467(13,3 \%)$ & $235(14,4 \%)$ \\
\hline STEMI PCI & $3495(18,9 \%)$ & $356(22 \%)$ \\
\hline Prior TRA & $1-88(\mathrm{~min})$ & $0-80(\mathrm{~min})$ \\
\hline Fluoroscopy time & $10-300$ (min) & $10-180(\min )$ \\
\hline
\end{tabular}

* CAD - Coronary artery disease; PCI - Percutaneous coronary intervention; STEMI — ST segment elevation myocardial infarction; CAS - Carotid artery stenting 
Most frequent radial artery anomaly was the high-bifurcating radial artery originating from the axillary and brachial arteries found in 1017 (5.5\%) patients. Full radial loop was present in $176(0.95 \%)$ patients and $227(1.2 \%)$ patients had extreme radial artery tortuosity, $32(0.17 \%)$ had hypoplastic radial artery, $173(0.9 \%)$ had tortuous brachial, subclavian and axillary arteries, which is shown in Table 3.

Table 3. Anatomical variants among patients with TRA

\begin{tabular}{|l|c|}
\hline Anatomical variants & Incidence \\
\hline Total Number of patients with present anomalies & $1625(8,8 \%)$ \\
\hline $\begin{array}{l}\text { High bifurcating origin of the radial artery from } \\
\text { the brachial or axillary arteries }\end{array}$ & $1017(5,5 \%)$ \\
\hline Radial artery loop $\left(360^{\circ}\right)$ & $176(0,95 \%)$ \\
\hline Radial artery tortuosity & $227(1,2 \%)$ \\
\hline Hypoplastic radial artery & $32(0,17 \%)$ \\
\hline Loop of the brachial/axillary/subclavian artery & $173(0,9 \%)$ \\
\hline
\end{tabular}

Table 4. Secondary outcomes based on present $R A$ anomalies

\begin{tabular}{|l|c|c|c|}
\hline & $\begin{array}{c}\text { RA anomalies } \\
\text { group } \\
\mathrm{N}=1625 \\
(8,8 \%)\end{array}$ & $\begin{array}{c}\text { RA without } \\
\text { anomalies } \\
\mathrm{N}=16790 \\
(91,2 \%)\end{array}$ & P value \\
\hline $\begin{array}{l}\text { Clinical radial artery } \\
\text { spasm }\end{array}$ & $206(12,6 \%)$ & $471(2,5 \%)$ & $<0,001$ \\
\hline $\begin{array}{l}\text { Access site bleeding } \\
\text { complications }\end{array}$ & $133(8,2 \%)$ & $1290(7,7 \%)$ & \\
\hline
\end{tabular}

* RA — radial artery

Table 5. Access site complications

\begin{tabular}{|l|c|}
\hline Access site complications & $\%$ \\
\hline Clinical radial artery spasm & $206(12,6 \%)$ \\
Grade I & $40 / 1625=2,5 \%$ \\
Grade II & $84 / 1625=5,2 \%$ \\
Grade III & $67 / 1625=4,1 \%$ \\
Grade IV & $15 / 1625=0,9 \%$ \\
\hline Access site bleeding complications & $133(8,2 \%)$ \\
\hline Haemathoma grade 1 & $43 / 1625=2,6 \%$ \\
\hline Haemathoma grade 2 & $56 / 1625=3,4 \%$ \\
\hline Haemathoma grade 3 & $20 / 1625=1,2 \%$ \\
\hline Haemathoma grade 4 & $11 / 1625=0,7 \%$ \\
\hline Haemathoma grade 5 & $3 / 1625=0,2 \%$ \\
\hline Major vascular complications & $0 \%$ \\
\hline * RA - Radial artery & \\
\hline
\end{tabular}

Clinical radial artery spasm was significantly more frequent in cases with present anomalies $12 \%$, compared to cases without present anomalies $2.5 \%$ respectively $(\mathrm{p}<0,001)$. In 82 cases high grade IV and V clin- ical spasm was present (5\%), which is shown in Table 4. Access site bleeding complications were similar in both groups with 8,2 and $7.7 \%$ respectively.

Haematoma grades IV and V were present in 14 cases which resolved without clinical consequences. None of the patients needed vascular repair of the puncture site, which is shown in Table 5.

\section{DISCUSSION}

We can conclude that radial artery anomalies are very common in the Macedonian population with a 8.8 percentage registered in our study in a large patient cohort. These results were analysed from the data of the the largest national center for percutaneous angiography procedures in Macedonia in the period of 4 years. Our PCI center has $98 \%$ take of all angiography procedures performed in our country. $95 \%$ of all angiography procedures in our center were performed with transradial artery access, with $4.2 \%$ using transulnar artery access. Only $0.3 \%$ of all procedures in this period were performed using transfemoral approach.

Considering the recognition given by the European cardiology panel consensus document (1) that the transradial approach should be the default approach for PCI in experienced transradial centers, it is important to understand any issues that could influence success of TRA percutaneous interventions. Even in peripheral interventions transradial approach is starting its momentum. Insufficient devices for peripheral radial artery stenting still limit its use in peripheral angiography interventions (17-23). The reported overall failure in transradial procedures is between $1 \%$ and $7 \%(16)$.

It is highly likely that radial artery anomalies influence the success of transradial agiography procedures.

Knowledge of present radial artery anomalies with pre-procedural radial artery angiography can help the interventionalist to evaluate the present anomaly and plan the angiography procedure without sacrificing procedure time or success.

We strongly encourage the use of radial artery angiography before the beginning of every transradial procedure giving the operator a chance to identify present anomalies and plan the procedure accordingly, making TRA failure less likely.

\section{Study limitations}

The definition of clinical radial artery spasm was subjective, made by presence of clinical signs. Also the hemostasis technique was not uniform.

\section{CONCLUSION}

Radial artery anomalies are very common in the general population. Knowing the anatomy of the radial 
artery helps the interventional cardiologist successfully plan and perform the angiography procedure. Most of the present obstacles in TRA anomaly cases can be successfully overcome by experienced radial operators. Radial artery angiography is strongly encouraged in every patient before the begining of transradial angiography procedures.

\section{Conflict of interest}

Nothing to declare.

\section{Source of Funding}

There were no external funding source for this study.
Abbreviations
TRA - Transradial approach
RA - Radial artery
TFA - Transfemoral approach
TUA - Transulnar approach

\title{
Sažetak
}

\section{ANOMALIJE RADIJALNE ARTERIJE U MAKEDONSKOJ POPULACIJI TOKOM TRANSRADIJALNIH ANGIOGRAFSKIH PROCEDURA}

\author{
Zafirovska Biljana, Petkoska Danica, Antov Slobodan, Vasilev Ivan, Jovkovski Aleksandar, \\ Kalpak Oliver, Kostov Jorgo, Spiroski Igor, Pejkov Hristo, Bosev Marjan, Taravari Hajber, \\ Kitanoski Darko, Kedev Sasko \\ University Clinic of Cardiology, University of Sts.Cyril and Methodius, Skopje, R. Macedonia
}

Cilj: utvrditi učestalost anomalija radijalne arterije registrovanih kod makedonske populacije tokom angiografija sa transradijalnim pristupom (TRA), na velikom uzorku pacijenata.

Uvod: Transradialna angiografija (TRA) je sada preporučen pristup za perkutane koronarne intervencije, ali tehnički je još uvek više izazovan pristup za angiografiju, uglavnom zbog anatomskih anomalija na radijalnoj arteriji, što može uticati na uspešnost transradijalnih angiografskih procedura.

Metode: od marta 2011. do decembra 2014.godine, u nasem Centru pregledano je ukupno 19292 uzastopnih pacijenata. Preproceduralna radijalna angiografija je sprovedena kod svih bolesnika. Analizirane su kliničke i proceduralne karakteristike, vrsta i učestalost vaskularnih anatomskih varijanti i komplikacije.

Rezultati: Anatomske modifikacije su bile prisutne kod 1625 (8,8\%) pacijenata. Većinom se radilo o vi-

\section{REFERENCES}

1. Hamon M, Pristipino C, Di Mario C et al. Consensus document on the radial approach in percutaneous cardiovascular interventions: position paper by the European Association of Percutaneous Cardiovascular Interventions and Working Groups on Acute Cardiac Care and Thrombosis of the European Society of Cardiology. EuroIntervention. 2013; 8(11): 1242-51.

2. Rodriguez-Niedenfuhr M, Vazquez T, Nearn L, Ferreira B, Parkin I, Sanudo JR. Variations of the arterialpattern in the upper limb revisited: a morphological and statistical study, with a review of the literature. J Anat. 2001; 199(Pt 5): 547-66. sokoj-bifurkaciji radijalne arterije od aksilarne i brahijalne arterije i to kod 1017 (5,5\%) pacijenata, 227 $(1,2 \%)$ pacijenata je imalo izuzetnu zakrivljenost radijalne arterije, $176(0,95 \%)$ je imalo pun radijalni luping, $32(0,17 \%)$ je bilo sa hipoplastičnom radijalnom arterijom i $173(0,9 \%)$ je imalo tortuozne brahijalne, subklavijalne i aksilarne arterije. Spazam radijalne arterije je bio vrlo čest kod pacijenata s prisutnim anomalijama radijalne arterije.

Zaključak: Anomalije radijalne arterije su vrlo česte u opštoj populaciji. Poznavanje anatomije radijalne arterije pomaže interventnim kardiolozima u uspešnom planiranju i izvođenju ovog postupka. Angiografija radijalne arterije se preporucuje kod svakog pacijenta pre izvođenja transradijalne angiografije.

Ključne reči: TRA (transradijalni arterijski pristup), RA ( radijalna arterija), TFA (tranfemoralni arterijski pristup), vaskularne anatomske varijacije.

3. McCormack Lj, Cauldwell EW, Anson BJ. Brachial and antebrachial arterial patterns; a study of 750 extremities. Surg Gynecol Obstet. 1953; 96(1): 43-54.

4. Burzotta F, Brancati MF, Trani $C$ et al. Impact of radialto-aorta vascular anatomical variants on risk of failure in transradial coronary procedures. Catheter Cardiovasc Interv. 2012; 80(2): 298-303.

5. Lo TS, Nolan J, Fountzopoulos E et al. Radial artery anomaly and its influence on transradial coronary procedural outcome. Heart. 2009; 95(5): 410-5.

6. Valsecchi O, Vassileva A, Musumeci G et al. Failure of transradial approach during coronary interventions: anatomic considerations. Cathet Cardiovasc Interv. 2006; 67(6): 870-8. 
7. Nie B, Zhou YJ, Li GZ, Shi DM, Wang JL.Clinical study of arterial anatomic variations for transradial coronary procedure in Chinese population. Chin Med J (Engl). 2009; 122(18): 2097-102.

8. Uglietta JP, Kadir S. Arteriographic study of variant arterial anatomy of the upper extremities. Cardiovasc Intervent Radiol. 1989; 12(3): 145-8.

9. Yoo BS, Yoon J, Ko JY, et al. Anatomical consideration of the radial artery for transradial coronary procedures: arterial diameter, branching anomaly and vessel tortuosity. Int J Cardiol. 2005; 101(3): 421-7.

10. Rao SV, Ou FS, Wang TY et al. Trends in the prevalence and outcomes of radial and femoral approaches to percutaneous coronary intervention: a report from the National cardiovascular data registry. JACC Cardiovasc Interv. 2008; 1(4): 379-86.

11. Pristipino C, Trani C, Nazzaro MS et al. Major improvement of percutaneous cardiovascular procedure outcomes with radial artery catheterisation: results from the PREVAIL study. Heart. 2009; 95(6): 476-82.

12. Hetherington SL, Adam Z, Morley R et al. Primary percutaneous coronary intervention for acute ST-segment elevation myocardial infarction: changing patterns of vascular access, radial versus femoral artery. Heart. 2009; 95(19): 1612-8.

13. Rao SV, Cohen MG, Kandzari DE, Bertrand OF, Gilchrist IC. The transradial approach to percutaneous coronary intervention: historical perspective, current concepts, and future directions. J Am Coll Cardiol. 2010; 55(20): 2187-195.

14. Goldsmit A, Kiemeneij F, Gilchrist IC, et al. Radial artery spasm associated with transradial cardiovascular procedures: Results from the RAS registry. Catheter Cardiovasc Interv. 2014; 83(1): E32-6. doi: 10.1002/ccd.25082.

\author{
Correspondence to / Autor za korespondenciju \\ Sasko Kedev, MD, PhD, FESC, FACC \\ Professor of Cardiology, Medical Faculty, \\ University Clinic of Cardiology \\ University of St. Cyril \& Methodius \\ Vodnjanska 17, Skopje, Macedonia \\ Phone: +38923113116 , mobile no: +38970225662 \\ Fax: +38923164134 \\ Email: skedev@mt.net.mk
}

15. Kiemeneij F. Prevention and management of radial artery spasm. J Invasive Cardiol. 2006; 18(4): 159-60.

16. Bertrand OF, De Larochelliere R, Cabau JR et al. Early Discharge After Transradial Stenting of Coronary Arteries (EASY) study investigators. A randomized study comparing same-day home discharge and abciximab bolus only to overnight hospitalization and abciximab bolus and infusion after transradial coronary stent implantation. Circulation. 2006; 114(24): 2636-43.

17. Yoo BS, Yoon J, Ko JY, et al. Anatomical consideration of the radial artery for transradial coronary procedures: arterial diameter, branching anomaly and vessel tortuosity. Int $\mathrm{J}$ Cardiol. 2005; 101(3): 421-7.

18. Etxegoien N, Rhyne D, Kedev S, Sachar R, Mann T. The transradial approach for carotid artery stenting. Catheter Cardiovasc Interv. 2012; 80(7): 1081-7.

19. Hawkins BM, Drachman DE. Transradial access for carotid stenting: exceptional outcomes in experienced hands... will the results be generalizable? Catheter Cardiovasc Interv. 2012; 80(7): 1088-9.

20. Trani C, Tommasino A, Burzotta F. Pushing the limits forward: transradial superficial femoral artery stenting. Catheter Cardiovasc Interv. 2010; 76(7): 1065-71.

21. Luo JF, Wang HY, Huang WH, et al.Transradial artery intervention: an alternative approach for renal artery stent implantation? Chin Med J (Engl). 2012; 125(18): 3340-3.

22. Trani C, Tommasino A, Burzotta F. Transradial renal stenting: why and how. Catheter Cardiovasc Interv. 2009; 74(6): 951-6.

23. Louvard Y, LefPvre T. Loops and transradial approach in coronary diagnosis and intervention. Catheter Cardiovasc Interv. $2000 ; 51(2): 250-2$. 